Eshmuratov Bakhodir Beshimovich, cand. tech. sciences, Tashkent Scientific Research Institute of Chemical Technology of the Republic of Uzbekistan

E-mail:bbeshmuratov@mail.ru

Karimov Masud Ubaydulla ugli, doc. tech. sciences, Tashkent Scientific Research Institute of Chemical Technology of the Republic of Uzbekistan

E-mail: adler_219@mail.ru

Jalilov Abdulakhat Turapovich, academician, doc. chem. Sciences, prof.,

Tashkent Scientific Research Institute of Chemical Technology of the Republic of Uzbekistan

E-mail:a.t.djalilov@mail.ru

\title{
STUDY OF OPTIMIZATION OF SYNTHESIS METHYLDIETHANOLAMINE
}

\begin{abstract}
In the paper was studied the optimal ratio of ethylene oxide to methylamine for the preparation of methyldiethanolamine. The optimum molar ratio of methylamine with ethylene oxide having a degree of conversion of 60-70\%, which allows to determine the upper limit of the degree of conversion of $70 \%$.

Keywords: methylethanolamine, ethylene oxide, methylamine, methylmonoethanolamine, methyldiethanolamine.

In the production of methylethanolamines there is a large number of ethanolamines in the produced product. In the cleaning of natural gas, methyldiethanolamine is commonly used, and methylmonoethanolamine is used in small quantities or in no other way. Based on this, most manufacturers of methylethanolumineers have infused their technology for the production of methyldiethanolamine. Methyl monoethanolamine is added to the reaction mixture to increase the yield of methyldiethanolamine [1-2; 6-11].

In Fig. 1, the calculated behavior of methylethanolamine in the mixing reactor versus methanolamine and ethylene oxide is indicated. Methylamine was obtained on the basis of chloro-ammonium and formaline, and ethylene oxide was obtained on the basis of ethylene. The reactor is a type of autoclave and can withstand a pressure of 10-15 atm.

As seen from (Figure 1), in the absence of a methyl monoethanolamine (MMEA) recipe, the product obtained contains a large number of MMEAs. In (Figure 2), the estimated decoupling behavior of ethanolamines in the mixing reactor is relative to the methylamine and ethylene oxide ratio.

As seen from (Figure 2), with an increase in the amount of methylmonoethanolamine, the methyldiethanolamine production in the recycle increased and the output of methylmonoethanalamine decreased.

The dependence of the composition of ethanolamines, for the considered variant, on the amount of methyl monoethanolamine recycle in the initial mixture. When the value of the parameter, which corresponds to $3.2 \mathrm{~kg}$ of recycled methyl monoethanolamine per $1 \mathrm{~kg}$ of initial ethylene oxide, are obtained methyl ethanolamines composition of
\end{abstract}


MMEA: MDEA = $48: 58 w t . \%$, indicating a very limited scope of this process.

Objectively, methyl monoethanolamine recycle, acceptable for today's production conditions, reflecting the market value of individual methylethanolamines and allowable energy costs, is at the level of $2 \mathrm{~kg} / \mathrm{kg}$. With such a recycle value of methyl monoethanolamine, the content of methyldiethanolamine is about $43 \%$ of the mass. The proportion of methyldiethanolamine can be increased, as mentioned above, by distributing the input of recycled methyl monoethanolamine.

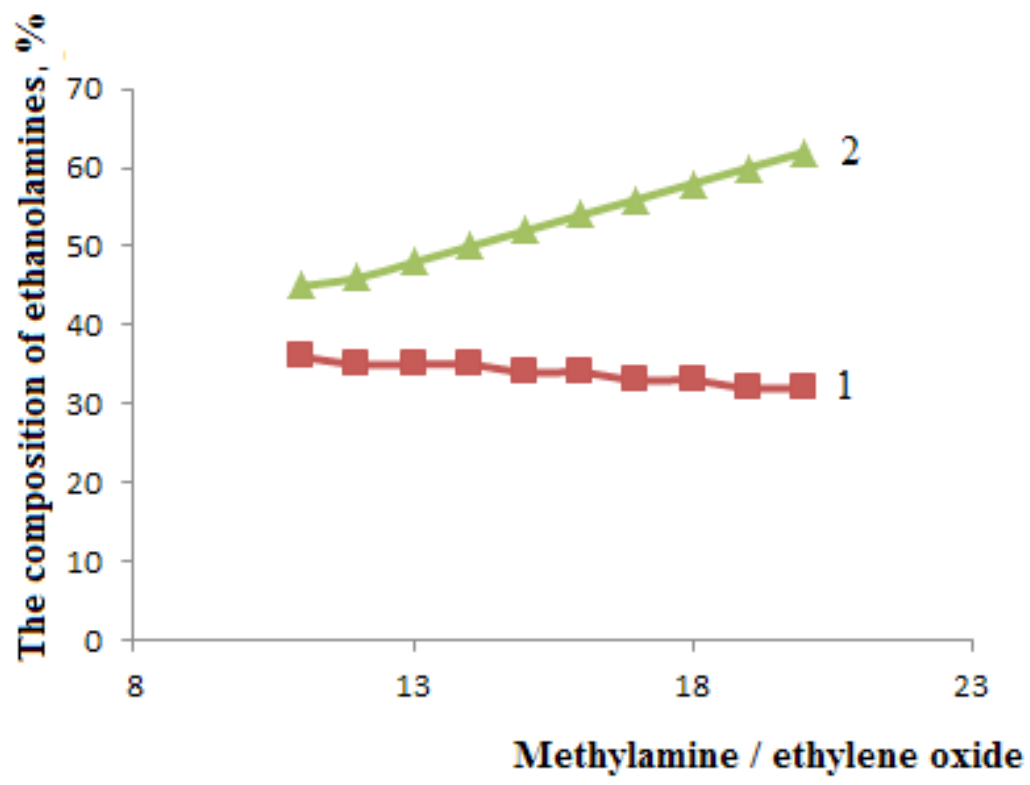

1 - methyldiethanolamin; 2 - methylmonoethanolamine

Figure 1. Recognizing the behavior of ethanolamines in the mixing reactor to reduce the methylamine and ethylene oxide in the distance of the MMEA at a temperature of $70{ }^{\circ} \mathrm{C}$

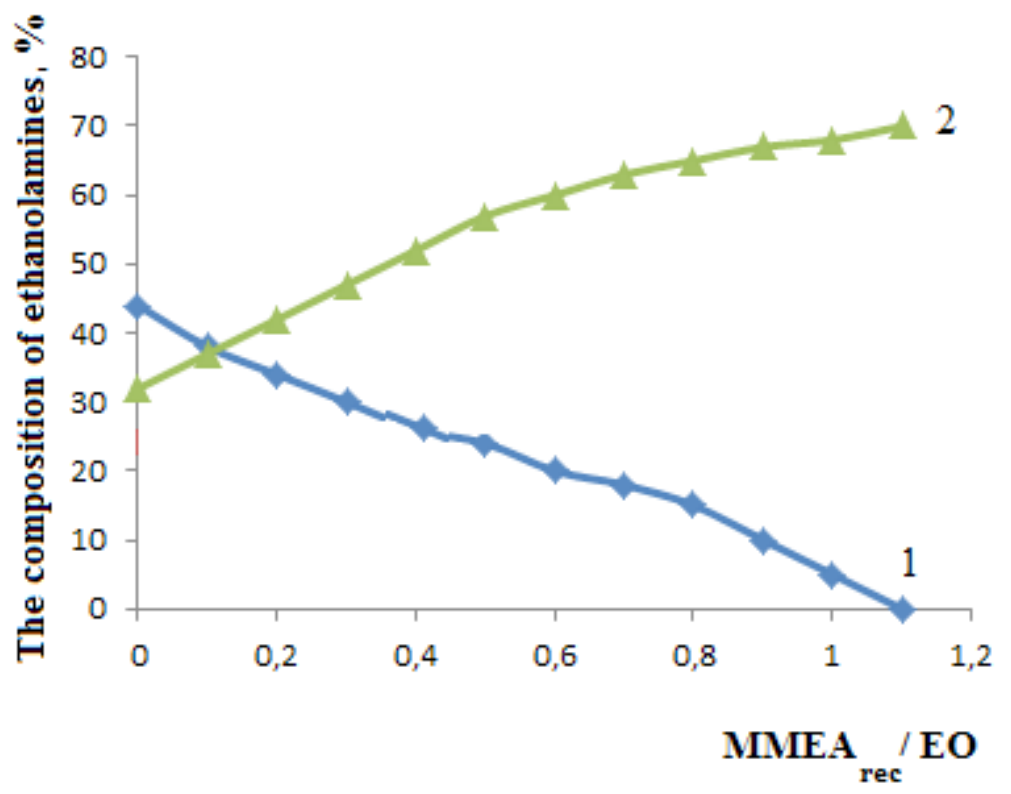

1 - Methylmonoethanolamine; 2 - Methyldiethanolamin

Figure 2. Calculation content of ethanolamines in the reactor for the mixing of methylamine and ethylene oxide at MMEA $_{\text {rec }}$ 
In (figure 3) shows the calculated dependence of ing reactor on the ratio of methyl monoethanolamine the composition of methylethanolamines in the mix- $\quad$ and ethylene oxide recycle with $\mathrm{MMEA} / \mathrm{OE}=21$.

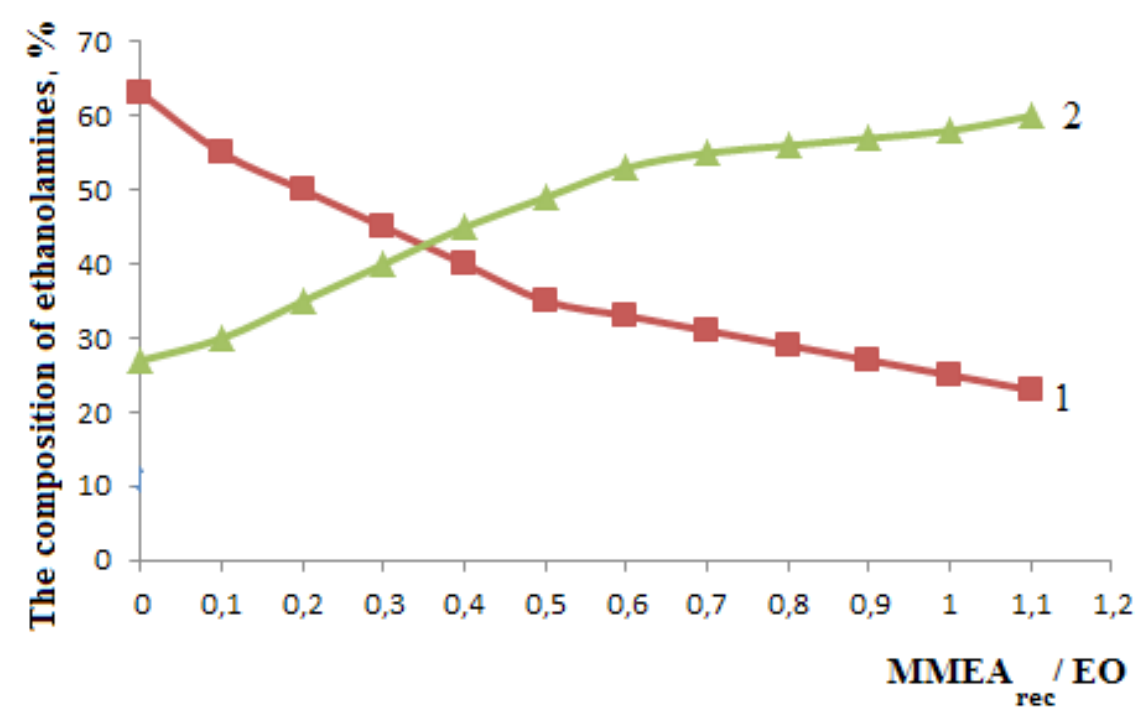

1 - methylmonoethanolamine; 2 - methyldiethanolamine

Figure 3. The calculated dependence of the composition of methylethanolamines

in the mixing reactor on the ratio of methyl monoethanolamine and ethylene oxide recycle at $\mathrm{MMEA}_{\mathrm{rec}} / \mathrm{OE}=21$ and at a temperature of $70{ }^{\circ} \mathrm{C}$

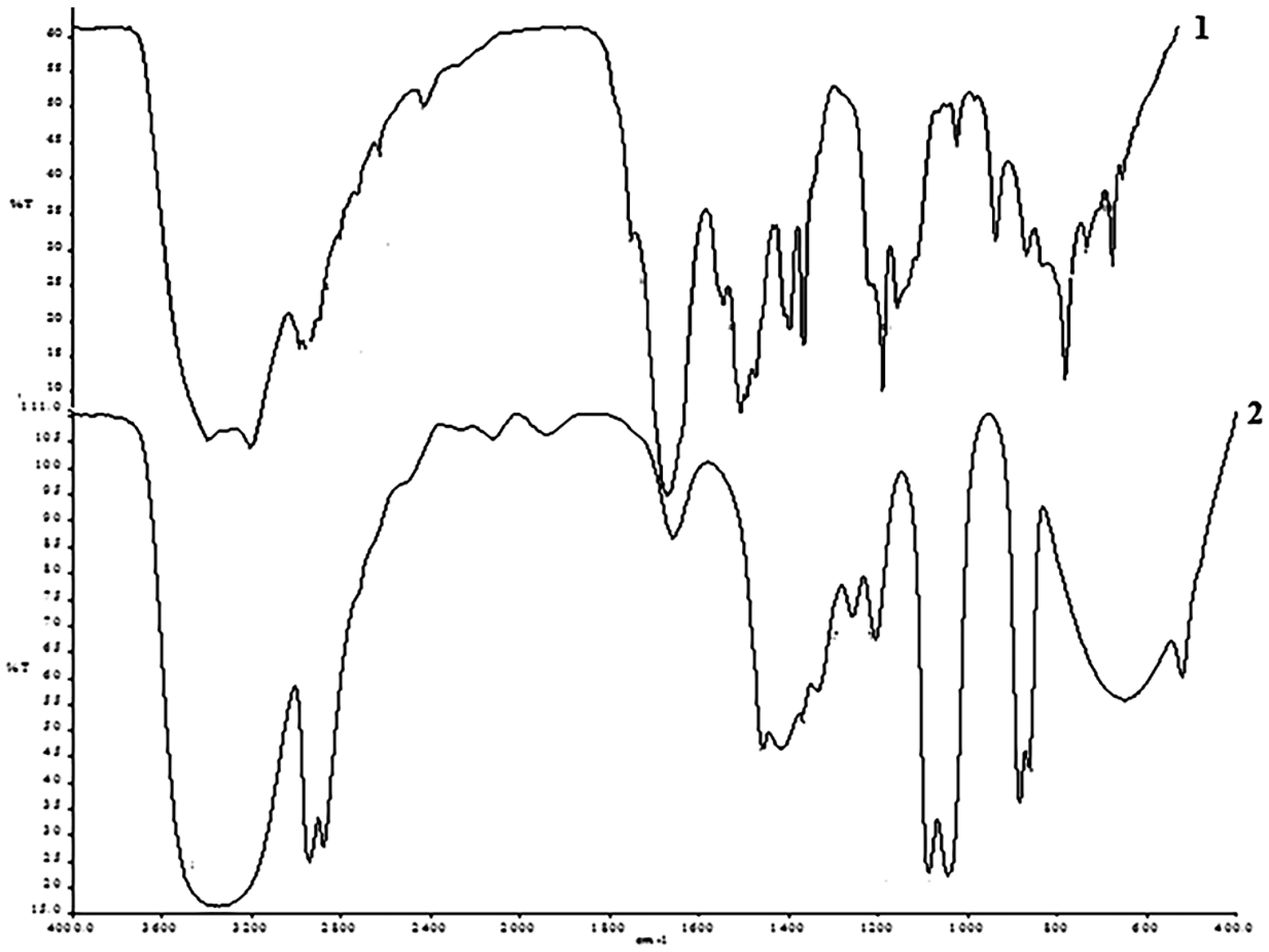

Figure 4. IR spectra of ethylene oxide (2) and methyldiethanol amine (1) 
As can be seen from $\mathrm{f}$ (igure 3 ), an increase in the amount of methyl monoethanolamine in recycling leads to an increase in the amount of methyldiethanolamine.

To obtain a mixture with a high content of MDEA, MMEA is returned to the initial mixture and displaced.

The functional groups of the obtained methyldiethanolamine were studied by the method of IR spectroscopy and were compared with the IR spectra of ethylene oxide.

Figure 4 shows the IR spectra of ethylene oxide and methyldiethanolamine.

As can be seen in Figure 4 (2), the absorption bands in the regions 1050, 1250, 3350-3310, and $3500 \mathrm{~cm}^{-1}$ are characteristic of the $-\mathrm{CH}_{2}-\mathrm{OH}$ functional groups in the composition of ethylene oxide with water. Absorption bands in the region of $800-600 \mathrm{~cm}^{-1}$ are characteristic of $-\mathrm{C}-\mathrm{O}-$ functional groups, which react with ammonia and form ethanolamines.

As can be seen in Figure 4 (1), the absorption bands in the region of 3350-3310, 3500 and $1580-1490 \mathrm{~cm}^{-1}$ are characteristic of the chemical bond $-\mathrm{NH}^{-}$. Absorption bands in the region of $1050,1250,3640,3350-3310$, and $3500 \mathrm{~cm}^{-1}$ are characteristic for functional groups $-\mathrm{CH}_{2}-\mathrm{OH}$ in diethanolamine.

The intensity of the absorption bands in the region of $3350-3310 \mathrm{~cm}^{-1}$ is especially weak for diethanolamine. The absorption bands in the region of $1580-1490 \mathrm{~cm}^{-1}$ are usually difficult to determine, because they are masked by the oleiphyne band in the region of $1580 \mathrm{~cm}^{-1}$.

In addition to these absorption bands, there are some absorption bands belonging to $-\mathrm{C}-\mathrm{O}-$ bonds, which show the existence of nonreacting ethylene oxide.

Thus, when studying the IR spectra, it has been established that the ethanolamines obtained have characteristic absorption bands for the amine and methylol groups.

It was established that the optimum ratio of ethylene oxide and methylamine for the preparation of methylethanolamines is $1: 21$, and the optimum temperature is $70^{\circ} \mathrm{C}$. Experimental data show that the acceptable content of MDEA (methyldiethanolamine) $60-70 \%$ at the exit is obtained at an initial molar ratio of methylamine-ethylene oxide 1: 19-25 and a conversion degree of $60-70 \%$, which allows to determine the upper limit of the degree of conversion at $70 \%$.

\section{References:}

1. Ethanolamines. Technical Bulletin “Oxiteno".- Brazil, 2002.- 4 p.

2. Ethanolamine. Monoethanolamine, diethanolamine, triethanolamine: Technical bulletin / "Dow Chemical Company”. Midland, USA, 2003.- 20 p.

3. Patent № 2162461 RF, MKI S07S213G` 04 Sposob polucheniya etanolaminov. Roleev G. I., Mixaylova T.A., Nikuhenko N. T., Lugovskoy S. A.(RF) - № 2000112562G` 04, zayavl. 22.05.2000, Opubl. 27.01.2001, Byul. № 3.

4. Patent № 2167147 RF, MKI S07S215G`08 Sposob polucheniya etanolaminov G’ Ro`leev G.I., Mixaylova T.A., Nikuhenko N. T., Lugovskoy S.A.(RF) - № 2000119218G` 04, zayavl. 20.07.2000, opubl.20.05.2001 Byul. № 14.

5. Patent № 2225388 RF, MKI S07S213G` 04. Sposob polucheniya etanolaminov T.A. Mixaylova, S. A. Lugovskoy, N. T. Nikuhenko, M. I. Nagrodskiy, I. A. Lavrentev (RF). № 2003105171G` 04; Zayavl. 21.02.2003, Opubl. 10.03.2004, Byul. No. 7.

6. Sarkisov P.D. Problemo energo- i resursosberejeniya v ximicheskoy texnologii, nefteximii i biotexnologiiG`G`Ximicheskaya promo`shlennost, 2000.- No. 1.- P. 19-25. 
7. Gruzinov V.P. Ekonomika predpriyatiya.-M.: Finanso`i statistika, 2000.- 326 p.

8. Djalilov A. T., Xamidov A.A., Eshmuratov B. B., Karimov M.U. Issledovanie polucheniya okisi etilena iz etilenaG ' G'VIII Mejdunarodnaya nauchno-texnicheskaya konferentsiya "Gorno-metallurgicheskiy kompleks: dostijeniya, problemo` i sovremenno `e tendentsii razvitiya”, Navoiyskiy gosudarstvenno 'y gorno 'y institut, g. Navai., 19-21 noyabr, 2015.- P. 18-19.

9. Djalilov A.T., Xamidov A.A., Eshmuratov B.B., Karimov M.U. Izuchenie sinteza etanolaminov iz etilenxlorgidrinaG'G' VIII Mejdunarodnaya nauchno-texnicheskaya konferentsiya "Gornometallurgicheskiy kompleks: dostijeniya, problemo` i sovremenno `e tendentsii razvitiya”, Navoiyskiy gosudarstvennoy gorno 'y institut, g. Navai., 19-21 noyabr, 2015.- P. 13-14.

10. Djalilov A. T., Xamidov A.A., Eshmuratov B. B., Karimov M. U. Issledovanie sinteza etanolaminovG' G`Respublikanskaya nauchno-texnicheskaya konferentsiya “Aktualno`e problemo` innovatsionno `x texnologiy ximicheskoy, nefte-gazovoy i pihevoy promishlennosti” - Tashkent, 2015. - P.18-20. noyabr. - P. 33-34. 